\title{
SPECIFIC SILENCING OF LEUKEMIC ONCOGENES USING RNA-INTERFERENCE APPROACH
}

\author{
T. D. LEBEDEV $V^{\prime}$, P. V. SPIRIN ${ }^{\prime}$, N. N. ORLOVA ${ }^{1}$, A. S. GORNOSTAEVA', \\ C. STOCKING ${ }^{2}$, V.S. PRASSOLOV *

\begin{abstract}
${ }^{1}$ Engelghardt Institute of Molecular Biology, Russian Academy of Sciences, Moscow, Russia; ${ }^{2}$ Heinrich-Pette Institute of Experimental Virology and Immunology, Hamburg, Germany; *e-mail: prassolov45@mail.ru
\end{abstract}

\begin{abstract}
$R N A$-interference is an effective natural mechanism of post-transcriptional modulation of gene expression. RNA-interference mechanism exists as in high eukaryotes both animals and plants as well in lower eukaryotes and viruses. RNA-interference is now used as a powerful tool in the study of functional gene activity, and many essential for fundamental biology results were obtained with this approach. Also it is widely believed that RNA-interference could be used in working out of new therapeutic medicine against malignant, infectious and hereditary diseases. One of the main problems of these developments is search of effective methods of siRNA transfer into the target cells. At the present time different sorts of transfections or viral transduction are used for these purposes. The results of comparison of inhibition of expression of oncogene AML-ETO by synthetic siRNA and by recombinant lentiviruses coding for corresponding shRNA are presented in the article.
\end{abstract}

\section{Key words: retroviral vectors, $R N A$-interference, embryonic mouse fibroblasts.}

$\mathrm{T}$ he controlled silencing of target genes is important both for molecular biological studies and for related applied sciences: in particular, modern biomedicine.

Among the many gene silencing approaches (which include the use of anti-sense RNA, ribozymes, chemical blockers, and targeted mutagenesis), the most efficient approach is based on RNA-interference.

RNA- interference is a highly specific mechanism for the posttranscriptional silencing of target genes. It involves the degradation of the target gene mRNA. The degradation of mRNA occurs in a complex formed by short-interfering RNA oligonucleotides (siRNA) and cellular proteins such as endonucleases. The nucleotide sequence of siRNA is complementary to that of target gene mRNA.

In the past couple of years, the use of siRNA has become widespread in studies of gene functioning and gene interaction. The use of siRNA as next generation therapeutic agents in biomedicine is also being explored. It is possible that, in the near future, siRNA will be used for treating viral and oncological diseases.

Currently, short synthetic 21-22-bp doublestranded siRNA molecules are widely used to silence mammalian genes. A number of commercial firms synthesize siRNA oligonucleotides. These commercial firms have siRNA design tools availab- le on their websites (e.g., www.qiagen.com). Synthetic siRNA oligonucleotides are transferred into cells in vitro by lipofection. Since siRNA induces the degradation of mRNA (and not the protein directly), the silencing effect does not occur immediately after cell transfection. The silencing effect is generally noticeable within 18 hours of transfection: however, in the case of stable proteins, the silencing effect may be noticeable only 24-48 hours after transfection. The longevity of siRNA silencing is comparatively short, and different sources claim that the silencing effect lasts for 3-5 cell divisions. It should be noted that the longevity of siRNA silencing may depend on many factors, in particular the nature of the cells being transfected. Approaches have been developed to synthetically modify siRNA oligonucleotides, which enhance the longevity of siRNA silencing in cells. Such synthetically modified siRNA oligonucleotides are useful for the post-transcriptional silencing of genes that encode proteins with a long half-life.

For long-lasting gene silencing, shRNA expressing lenti- and retroviral vectors can be used. Nucleotide sequences encoding the sense and antisense strands of siRNA separated by a spacer sequence can be cloned into lenti- or retroviral vector constructs using standard molecular biological cloning techniques. The transcription of such nucleotide sequences leads to the formation of shRNA

\footnotetext{
Abbreviations: AML - acute myeloid leukemia, CBF - core binding factor, eGFP - enhanced green fluorescent protein, GTU - GFP transducing units, HDAC - histone deacetylase, IRES - internal ribosome entry site, NHR nervy homology region, RHD - runt homology domain, VSV-G - vesicular stomatitis virus G glycoprotein.
} 
molecules. shRNA molecules form a hairpin structure consisting of two complimentary strands separated by a loop. The cellular endonuclease dicer is responsible for the cleavage of shRNA molecules. As a result, the loop gets removed from shRNA molecules and double-stranded siRNA molecules are formed. These siRNA molecules are capable of initiating the degradation of target gene mRNA.

Within the framework of our project, we were able to silence the expression of activated oncogenes AML1-ETO (t8;21) and RUNX1(K83N) with the help of RNA interference. These activated oncogenes are frequently found in acute myeloid leukemia patients. We were able to compare the efficiency of gene silencing: (a) after the lipofection of oncogene-expressing model cell lines with synthetically modified double-stranded siRNA oligonucleotides and (b) after the transduction of oncogene-expressing model cell lines with shRNAexpressing recombinant lentiviral vector particles.

Oncogene-expressing model cell lines were obtained from murine SC1 embryonic fibroblast cell lines after their transduction with bicistronic retroviral vector particles. These retroviral vectors contained a bicistronic expression cassette comprised of the gene of interest and an eGFP marker gene separated by an IRES sequence and driven by a common promoter. The following genes were selected as genes of interest:

(1) The AML1-ETO fusion gene, which is formed as a result of the $\mathrm{t}(8: 21)$ chromosomal translocation

(2) The activated RUNX1(K83N) oncogene, which is formed as a result of a point mutation in the RUNX1 gene and leads to the substitution of lysine to asparagine in the 83 position of the RUNX1 protein. Since both the gene of interest and eGFP marker gene are driven by a common promoter, the expression levels of the gene of interest in cells can be evaluated based on the intracellular expression of the eGFP marker gene.

The typical results of transduction efficiency and transgene expression are shown in Fig. 1. Throughout the course of our work, we used the murine SC1 embryonic fibroblast cell line, the HEK 293 cell line, and two transgenic SC1 cell lines expressing either activated oncogene AML1ETO or RUNX1(K83N). All four cell lines were cultured in standard DMEM medium containing $10 \%$ FBS, 4 mM L-glutamine, $1 \mathrm{mM}$ sodium pyruvate, $100 \mathrm{mkg} / \mathrm{ml}$ streptomycin, and 100 units $/ \mathrm{ml}$ penicillin at $37{ }^{\circ} \mathrm{C}$ in a $5 \% \mathrm{CO}_{2}$ atmosphere.

The design and synthesis of double-stranded siRNA molecules was carried out in collaboration with the Institute of Chemical Biology and Fundamental Medicine, Siberian Branch of the Russian Academy of Sciences (ICBFM SB RAS). The

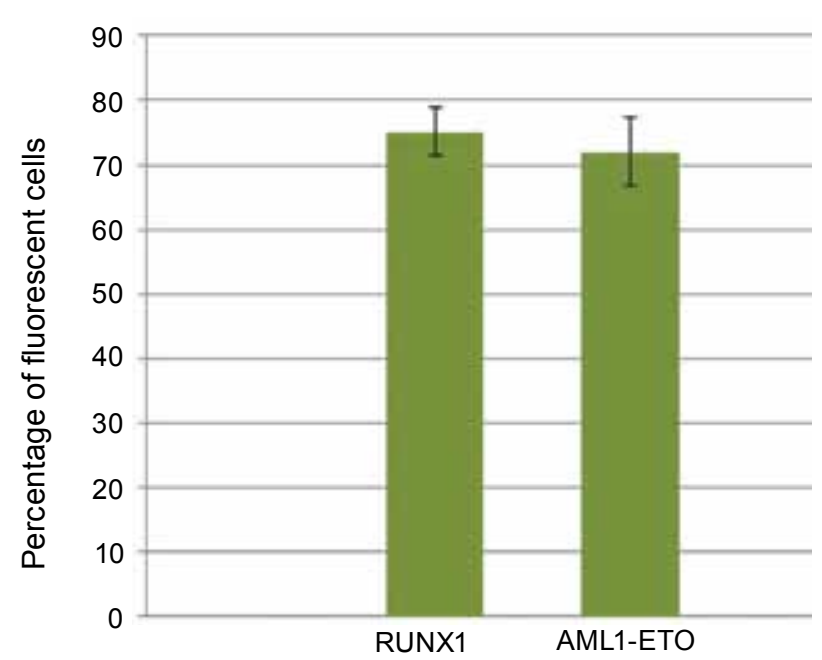

Fig. 1. Efficiency of transgene expression in $S C-1$ murine fibroblast cell lines transduced with AML1-ETO- and RUNX1-K83N-expressing recombinant retroviral vector particles

oligonucleotides were synthesized at ICBFM SB RAS using the phosphamide method. During oligonucleotide synthesis, a unique method was used to methylate the oligonucleotides at certain positions. These modifications significantly increase the lifespan of synthetic siRNA in cells. The nucleotide sequences of siRNA oligonucleotides:

AML1-ETO sense 5'-CCUCGAAAUCGUmACUmGAGUAG-3';

AML1-ETO antisense 5'-UCUCmAGUmAC-

GAUUUCGAGGUU-3';

ETO sense 5'-GGCCmAGCGGUmACmAGUCCmAGAU-3';

ETO antisense 5'-UUmGGACUmGUmACCGCUmGGCCUG-3';

AML(5') sense 5'-GAACCmAGGUUmGCmAAGAUUGAA-3';

AML(5') antisense 5'- AAAUCUUmGCmAACCUmGGUUCUU-3';

AML(3') sense 5'-AGCCCGGGAGCUUmGUCCUCUU-3';

AML(3') antisense 5'-AAGGACmAAGCUCCCGGGCUUmG-3'.

Anti-AML1-ETO and anti-RUNX1 siRNA duplexes were transferred into transgenic SC1 cell lines by lipofection using Lipofectamin2000 (Invitrogen) as per the manufacturers protocol. The final concentration of siRNA duplexes in the transfection culture medium was $200 \mathrm{nM}$. Four hours after transfection, the culture medium was changed to a fresh medium. The transfected cell lines were cultured at $37{ }^{\circ} \mathrm{C}$ in a $5 \% \mathrm{CO}_{2}$ atmosphere for 72 hours. 

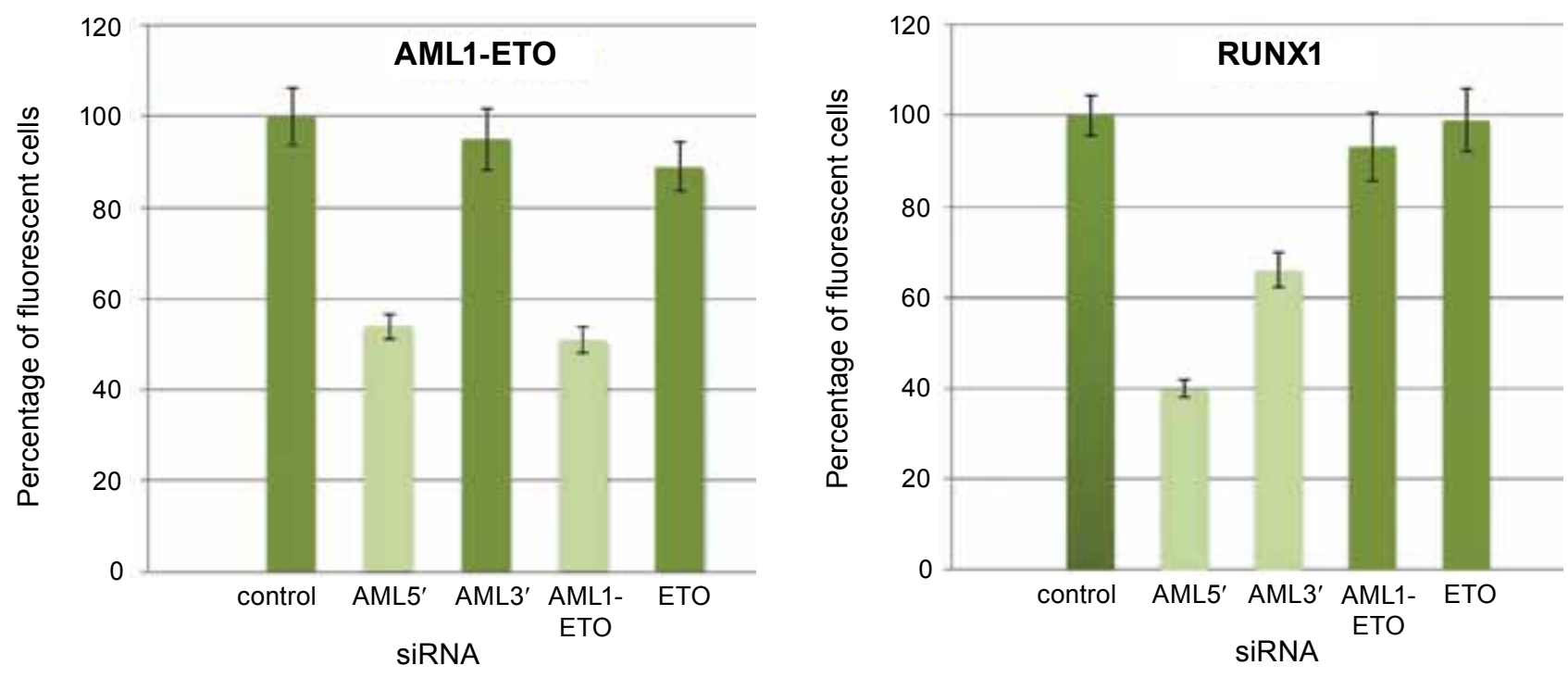

Fig. 2. Results obtained after flow cytometric analysis of cell suspensions. The percentage of fluorescent cells in the AML1-ETO and RUNX1 (K83N) expressing murine fibroblast cell lines 48 hours after transfection with various SiRNA duplexes

The level of oncogene expression in the cell lines was evaluated by reverse transcription PCR (RT-PCR) and flow cytometry. The total mRNA from the cell lines was extracted using TRIZOL (Invitrogen) as per the manufacturers protocol. The extracted mRNA was used to synthesize the first strands of cDNA using the ImProm-II ${ }^{\mathrm{TM}}$ reverse transcriptase (Promega) kit.

PCR with sequence-specific primers was carried out to identify the nucleotide sequences of the genes of interest and eGFP marker gene in the total cDNA. The following primers were used for RUNX1 (K83N):

sense-AGTCCTACCAATACCTGGGA; antisense-TCTCAGCTGTGGTGGTGAAG, for AML1/ETO:

sense-CATTTCACCCGAGATAGGAG; antisense-AAGTCCTCGGCGTCACTGAT, for eGFP:

sense-ACCTACGGCCTGCAGTGCTT; antisense-TGCCGTTCTTCTGCTTGTCG.

PCR products were then visualized after $1.5 \%$ agarose gel electrophoresis. The results were processed using the Gel-Pro Analyzer 4.0 software, which gives a maximum optical density (maxOD) reading. The results were normalized against $\beta$-actin.

Cell fluorescence was measured using an epics 4XL Beckman coulter flow cytometer (United States). The WinMDI2.8 software program was used for data collection and data analysis. The diagrams of the percentage of fluorescent cells in the cell populations are shown in Fig. 2. Cell popula- tions transfected with respective siRNA duplexes are shown along the $\mathrm{X}$ axis, while the percentage of fluorescent cells in the population is shown on the $\mathrm{Y}$ axis.

Results obtained by flow cytometry correlate well with the results obtained by RT-PCR. The electrophoregram of RT-PCR products is shown in Fig. 3. The reduction of oncogene mRNA is clearly visible in the SC1-AML1/ETO (t8;21) transgenic cell lines transfected with siRNA oligonucleotides targeting the 5'-end of RUNX1 mRNA, ETO mRNA and the site of junction of AML1-ETO mRNA. Oncogene mRNA reduction is also seen in the SC1-RUNX1(K83N) transgenic cell lines transfected with siRNA oligonucleotides targeting the 5'- and 3'-ends of RUNX1 mRNA.

While there is a significant reduction of fluorescence in a portion of the cell population (two times or more) after the addition of synthetic siRNA, there is no such reduction in fluorescence in the rest of the cell population (Fig. 2). This coincides with the results obtained by RT-PCR (Fig. 3). The most likely reason for this is the low efficiency of siRNA delivery into cells. According to the manufacturers of Lipofectamin2000 (Invitrogen), the lipofection efficiency with siRNA oligonucleotides is $50-60 \%$ and depends on the nature of the cells being transfected. Apart from this, there is the possibility of a reduction of synthetic siRNA activity due to their enzymatic degradation, which is catalyzed by cellular endonucleases, despite the stabilizing modifications introduced to the siRNA oligonucleotides. According to our 


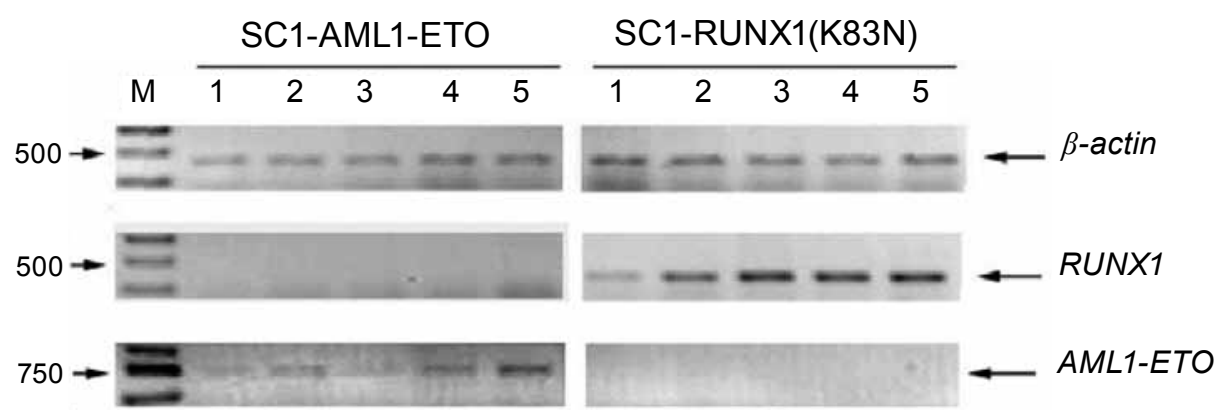

Fig. 3. The electrophoregram of RT-PCR products of total cDNA obtained from oncogene expressing model cell lines transfected with siRNA. 1 - siRNA(AML1-5'), 2 - siRNA(AML1-3'), 3 - siRNA(AML1-ETO), 4 SiRNA(ETO), 5 - Control (without siRNA)

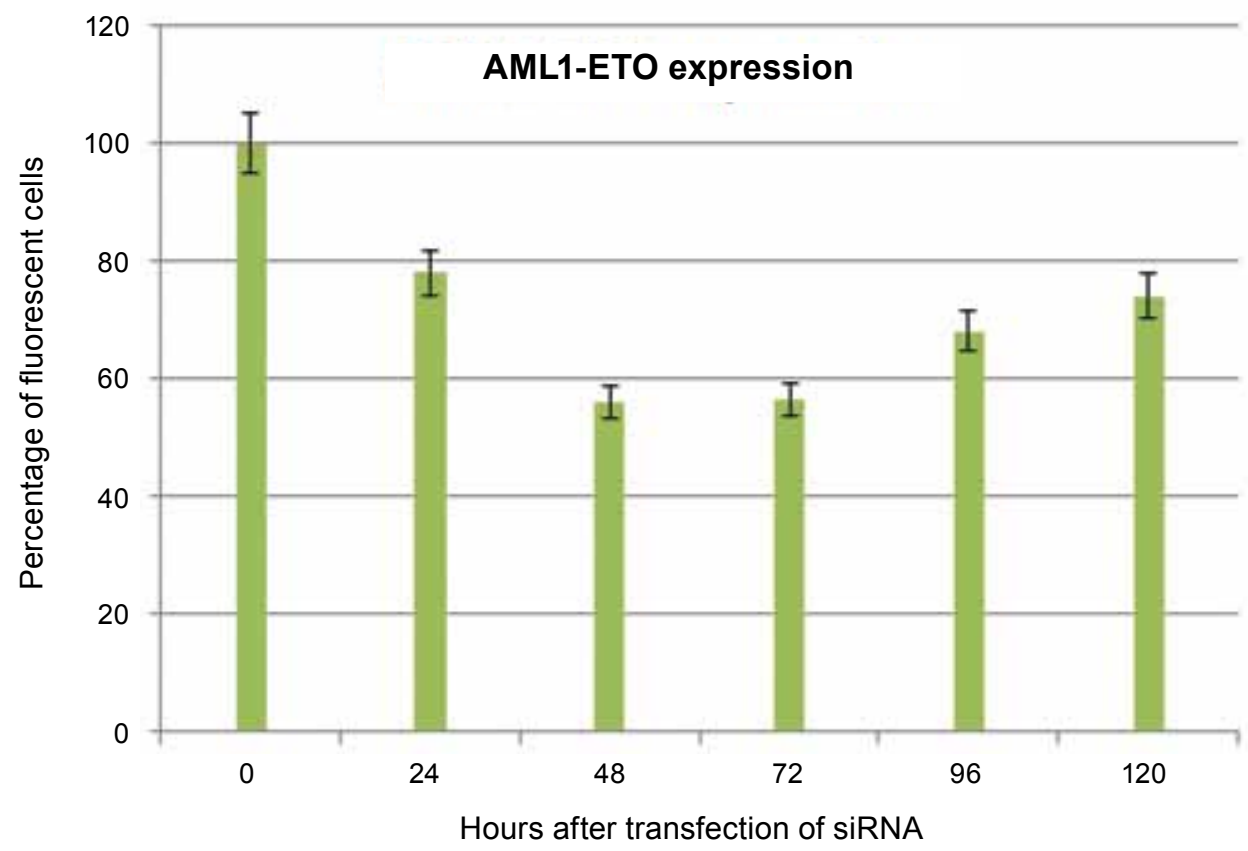

Fig. 4. The gene silencing kinetics of synthetic siRNA oligonucleotides targeting the junction point of AML1-ETO $m R N A$

data, the maximum interfering activity of synthetically modified siRNA is observed $48-72$ hours post transfection.

The gene silencing kinetics of synthetic siRNA oligonucleotides targeting the junction point of AML1-ETO mRNA is illustrated in Fig. 4. The moment of siRNA transfection has been taken as zero-time reference.

It has been shown that the maximum silencing activity of synthetic siRNA is $48-72$ hours post transfection, when the percentage of fluorescent cells in the population is around $56 \%$. The percentage of fluorescent cells in the population increases to 67, 92 and $74.39 \% 96$ and 120 hours post transfection, respectively. The results shown are averaged from three parallel measurements and are in reference to a control.
The efficiency of RNA-interference can be increased by increasing the efficiency of siRNA delivery into the model cell lines. For this purpose, taking into account the efficiency of the synthetic siRNA duplexes, two shRNA-expressing lentiviral vectors were constructed targeting the junction point of AML1-ETO mRNA and the 5'-end of RUNX1 mRNA, respectively. The lentivectors were constructed by cloning the shRNA-expressing DNA sequence into the pLSLP vector.

DNA sequence which encodes anti AML1ETO shRNA:

- AML1-ETO-sense 5'-p-GATCCGCCTCGAAATCGTACTGAGGCTTCCTGTCATCTCAGTACGATTTCGAGGTTTTTG-3'

- AML1-ETO antisense 5'-pAATTCAAAAACCTCGAAATCGTACTGAGA- 
A

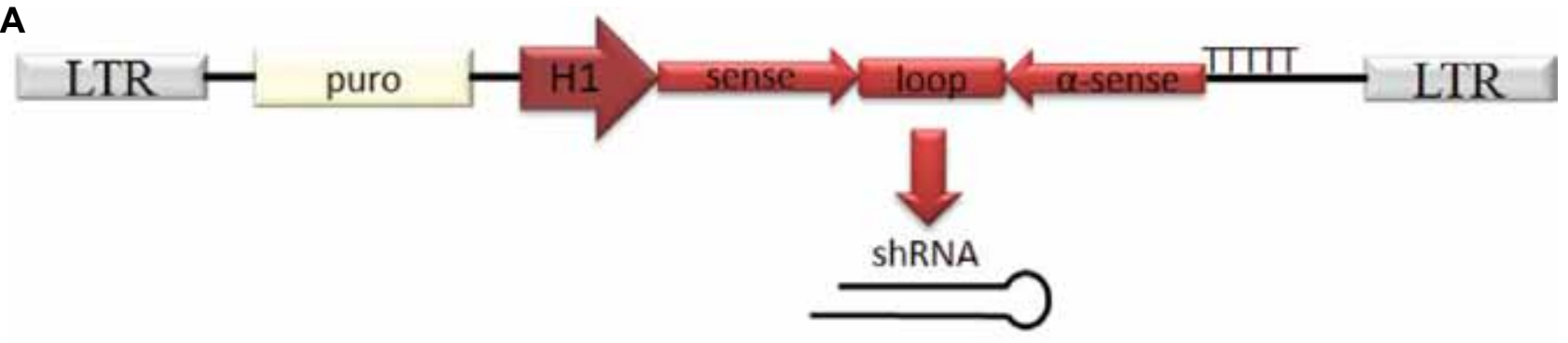

B
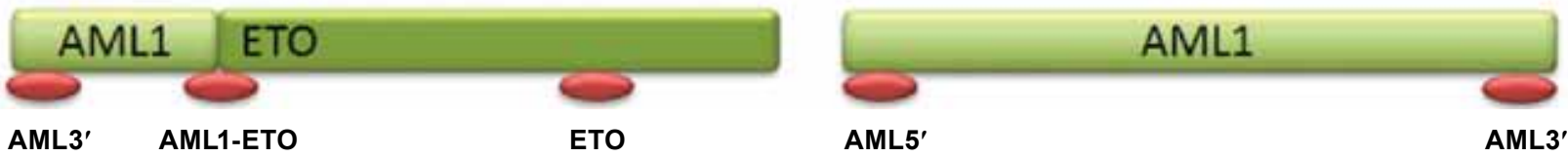

Fig. 5. shRNA expressing lentiviral vectors: $\boldsymbol{A}-$ Lentiviral vector expressing shRNA; $\boldsymbol{B}-$ siRNA targeting different oncogene zones

\section{TGACAGGAAGCCTCAGTACGATTTCGAG- GCG-3'} shRNA:

DNA sequence which encodes anti-RUNX1

- AML-5-sense 5'-p-GATCCGGAACCAGGTTGCAAGATTCCTTCCTGTCAAAATCTTGCAACCTGGTTCTTTTTG-3'

- AML-5-antisense 5'-p-AATTCAAAAAGAACCAGGTTGCAAGATTTTGACAGGAAGGAATCTTGCAACCTGGTTCCG-3'

The design of the shRNA-coding DNA sequences was done through an internet resource (http://gesteland.genetics.utah.edu/sirnA_scales/ index.html). Standard genetic engineering techniques were used for all cloning procedures. The shRNA-expressing lentiviral vectors are shown in Fig. 5.

The transient cotransfection of HEK293T cells with shRNA-expressing lentiviral vectors and packaging plasmids was done for the production of shRNA-expressing lentiviral vector particles. The transfection was carried out using Lipofectamin2000 (Invitrogen) as per the manufacturers' protocol. Viral stocks were harvested for three days and used for the infection/transduction of the transgenic model cell lines expressing the activated oncogenes AML1-ETO and RUNX1 $(\mathrm{K} 83 \mathrm{~N})$. Forty-eight hours after transduction/infection, the model cell lines were placed in culture media containing puromycin $(10 \mathrm{mkg} / \mathrm{ml})$ for five days. After selection for puromycin resistance, the shRNA expressing transduced model cell lines were analyzed by flow cytometry.

The percentage of fluorescent cells in the SC1-AML1/ETO(t8;21) transgenic cell line de- creased 6 times after their transduction with shRNA-expressing lentiviral vector particles targeting the junction point of AML1-ETO mRNA (Fig. 6). Similar results were seen when the SC1-AML1/ ETO $(\mathrm{t} 8 ; 21)$ and SC1-RUNX1(K83N) cell lines were transduced with shRNA-expressing lentiviral vector particles targeting the $5^{\prime}$-end of RUNX1 mRNA. The percentage of fluorescent cells in the cell lines decreased 8 and 8,5 times, respectively. It should be noted that the Sc1-RUNX1(K83N) cell line showed no reduction in fluorescence when transduced with shRNA-expressing lentivi-

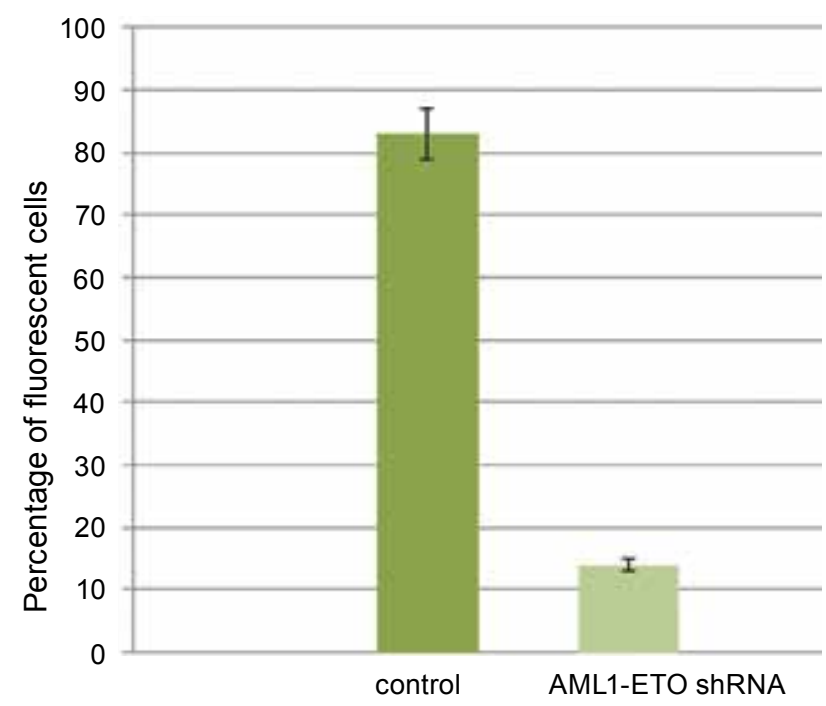

Fig 6. Histogram illustrating the reduction in fluorescence in the AML1-ETO expressing SC-1 murine fibroblast cell line before and after transduction with shRNA-expressing lentiviral vector particles targeting the junction point of the AML1-ETO $\mathrm{mRNA}$ 

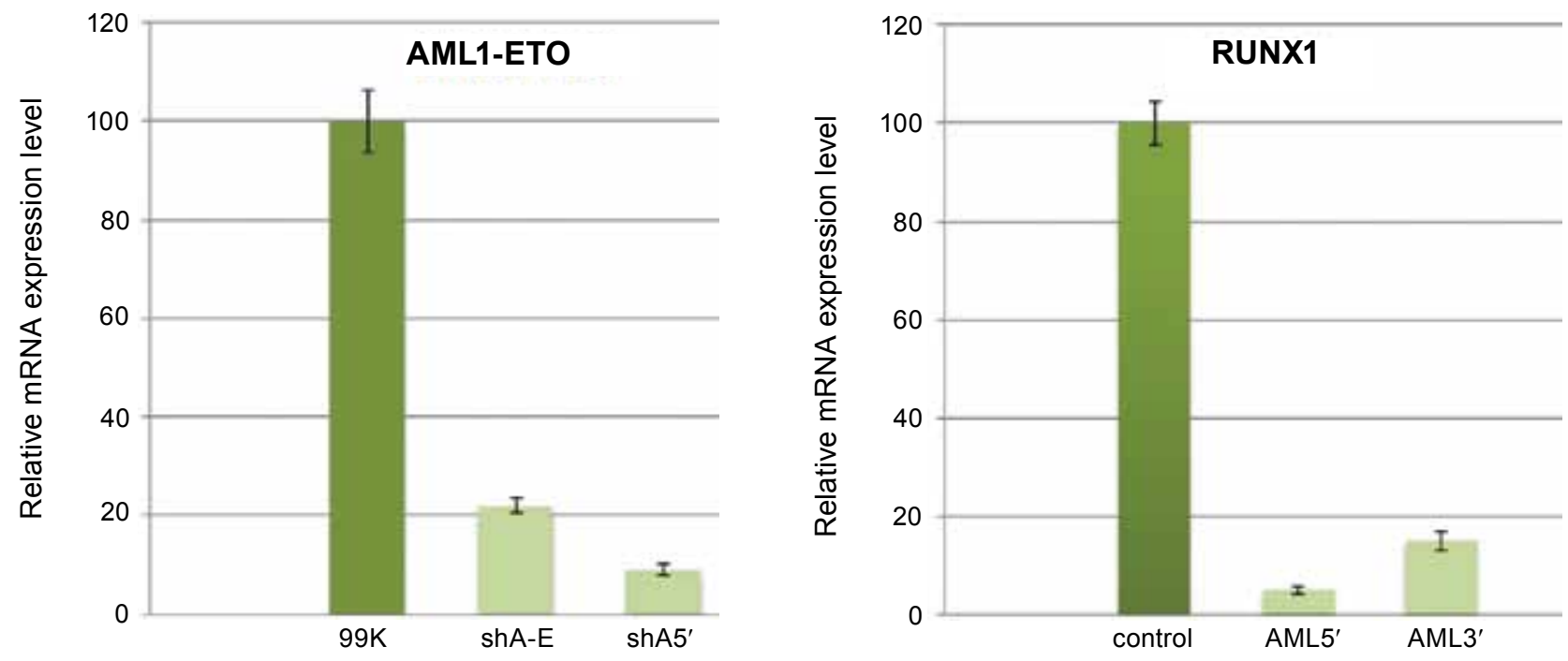

Fig. 7. The Real Time RT-PCR products of total cDNA obtained from RUNX1(K83N) and AML1-ETO oncogene expressing SC1 model cell lines transduced with shRNA expressing lentiviral vector particles: $99 \mathrm{~K}$ - control (non-transduced RUNX1(K83N) expressing SC1 cell line); shA-E-RUNX1(K83N) expressing SC1 cell line transduced with shRNA expressing lentiviral vector particles targeting the junction point of AML1-ETO mRNA; shA5' - RUNX1(K83N) expressing SC1 cell line transduced with shRNA expressing lentiviral vector particles targeting the 5'-end of RUNX1 mRNA; last three samples - Analysis of AML1-ETO(t8;21) expressing SC1 cell lines (98k - non transduced control, shA-E, sh5' - transduced with corresponding lentiviral vector particles)

ral vector particles targeting the junction point of AML1-ETO mRNA. The results obtained by flow cytometry correlate well with the results obtained by Real Time RT-PCR (Fig. 7).

Our results illustrate the high efficiency of stable synthetically modified siRNA duplexes for silencing the activated oncogenes frequently found in acute myeloid leukemia patients.

Validated siRNA sequences were used to design and synthesize shRNA-coding DNA sequences. The synthesized DNA sequences were cloned into a recombinant lentiviral vector. The shRNAexpressing lentiviral vector particles targeting the junction point of AML1-ETO mRNA and 5'-end of RUNX1 mRNA were used to transduce the oncogene-expressing model cell lines. The transduced model cell lines were analyzed by RT-PCR and flow cytometry. The analysis revealed a significant reduction in the expression of activated oncogenes in the transduced cell lines. This is indicative of the high efficiency of the constructed lentiviral vector constructs, which can be used for silencing target genes by RNA interference.

This work was supported by the Programms of the Presidium of the Russian Academy of Sciences "Molecular and Cell Biology», "Fundamental Research Basics in Nanotechnology and Nanomaterials», and the Russian Foundation for Basic Research (grant N 11-04-01365-a and N 1304-00599-a).

\section{СПЕЦИФИЧЕСКОЕ ПОДАВЛЕНИЕ ЛЕЙКЕМИЧЕСКИХ ОНКОГЕНОВ С ИСПОЛЬЗОВАНИЕМ ПОДХОДА РНК-ИНТЕРФЕРЕНЦИИ}

\author{
Т. Д. Лебедев ${ }^{1}$, П. В. Спирин ${ }^{1}$, \\ Н. Н. Орлова , А. С. Горностаева \\ С. Стокинг ${ }^{2}$ В. С. Прассолов ${ }^{*}$
}

${ }^{1}$ Институт молекулярной биологии им. В. А. Энгельгардта, РАН, Москва, Россия;

${ }^{2}$ Институт экспериментальной вирусологии и иммунологии Генриха-Петте, Гамбург, Германия; *e-mail: prassolov45@mail.ru

РНК-интерференция является эффективным природным механизмом посттранскрипционной модуляции генной экспрессии. Механизм РНК-интерференции есть у высших эукариотов - животных и растений, а также у низших эукариотов и вирусов. В настоящее время РНК-интерференция используется как мощный инструмент для изучения функциональной активности генов. С помощью этого подхода удалось достичь результатов, имеющих существенное значение для фундаментальной биологии. Известно, что РНК-интерференция может использоваться при производстве лекарственных препаратов для лечения злокачественных, инфекционных и наследственных болезней. Одной из основных проблем этих разработок является поиск эффективных ме- 
тодов переноса siРHK в клетки-мишени. Для этих целей используются разные виды трансфекции или вирусная трансдукция. В статье представлены результаты сравнения угнетения экспрессии онкогена AML-ETO с помощью синтетической sіРНК и кодирования с помощью рекомбинантных лентивирусов для соответствующей shPHK.

К л юч е вы е с л о ва: ретровирусные векторы, РНК-интерференция, фибробласты эмбриона мыши.

\section{СПЕЦИФІЧНЕ ПРИГНІЧЕННЯ ЛЕЙКЕМІЧНИХ ОНКОГЕНІВ ІЗ ВИКОРИСТАННЯМ ПІДХОДУ РНК-ІНТЕРФЕРЕНЦІї}

\section{Т. Д. Лебедєв ${ }^{1}$, П. В. Спірін ${ }^{1}$,}

Н. Н. Орлова ${ }^{1}$, А. С. Горностаєва ${ }^{1}$,

С. Стокінг², В. С. Прассолов ${ }^{*}$ *

'Інститут молекулярної біології ім. В. О. Енгельгардта, РАН, Москва, Росія;

${ }^{2}$ Інститут експериментальної вірусології і імунології Генріха-Петте, Гамбург, Німеччина; *e-mail: prassolov45@mail.ru

РНК-інтерференція є ефективним природним механізмом посттранскрипційної модуляції генної експресії. Механізм РНКінтерференції є у вищих евкаріотів - тварин і рослин, а також у нижчих евкаріотів і вірусів. На сьогодні РНК-інтерференція використовується як потужний інструмент для вивчення функціональної активності генів. За допомогою цього підходу вдалося досягти результатів, що мають істотне значення для фундаментальної біології. Відомо, що РНК-інтерференція може використовуватися у виробництві лікарських препаратів для лікування злоякісних, інфекційних та спадко- вих хвороб. Однією з основних проблем цих розробок є пошук ефективних методів переносу siPHK в клітини-мішені. Для цих цілей використовуються різні види трансфекції або вірусна трансдукція. У статті представлено результати порівняння пригнічення експресії онкогену AML-ETO за допомогою синтетичної sіPHK та кодування за допомогою рекомбінантних лентивірусів для відповідної shРНК.

К л ю чов і слова: ретровірусні вектори, РНК-інтерференція, фібробласти ембріона миші.

1. Vilgelm A. E., Chumakov S. P., Prasolov V. S. // Mol. Biology. - 2006. - 40, N 3. - P. 1-18.

2. Volkov A. A., Kruglova N. S., Meschaninova M. I. et al. Selective protection of nuclease-sensitive sites in siRNA prolongs silencing effect // Oligonucleotides. - 2009. - 19, N 2. - P. 191202.

3. Shuey D. J., McCallus D. E., Giordano T. // Drug Discov. Today. - 2002. - 7, N 20. P. $1040-1046$.

4. Stanistawska J., Olszewski W. L. // Arch. Immunol. Ther. Exp. (Warsz). - 2005. - 53, N 1. - P. 39-46.

5. Elbashir S. M., Harborth J., Weber K., Tuschl T. // Methods. - 2002. - 26, N 2. - P. 199-213.

6. Brummelkamp T. R., Bernards R., Agami R. // Science. - 2002. - 296, N 5567. - P. 550-553.

7. Satake N., Maseki N., Kozu T. et al. // Br. J. Haematol. - 1995. - 91, N 4. - P. 892-898.

8. Peterson L. F., Zhang D. E. // Oncogene. 2004. - 23, N 24. - P. 4255-4262.

9. Kravchenko J. E., Ilyinskaya G. V., Komarov P. G. et al. // Proc. Natl. Acad. Sci. USA. - 2008. - 105, N 17. - P. 6302-6307. 